\title{
Cement augmentation in spinal tumors: a systematic review comparing vertebroplasty and kyphoplasty
}

\author{
Authors Josh E Schroeder , Erika Ecker², Andrea C Skelly², Leon Kaplan \\ Institutions 1 Orthopedic Department, Hadassah Hebrew University Medical Center, Jerusalem, Israel \\ 2 Spectrum Research Inc, Tacoma, WA, USA
}

\section{ABSTRACT}

Study design: Comparative effectiveness review.

Study rationale: The spine is among the most common location for bony metastases. In many cases these metastases cause fractures leading to increased morbidity. Percutaneous cement augmentation techniques have been developed over the past decades for the treatment of these fractures; however, there are little data comparing these interventions.

Clinical question: Do comparative studies of vertebral cement augmentation for fractures caused by spinal tumors provide evidence of improved patient outcomes?

Methods: A systematic search and review of the literature was undertaken to identify studies published through June 8, 2011. Two individuals independently reviewed articles based on inclusion and exclusion criteria which were set a priori. Each article was evaluated using a predefined quality-rating system and an overall strength of evidence determined.

Results: The literature consists primarily of case series. Only two studies comparing vertebroplasty with kyphoplasty were found. Pain scores in both treatment groups were significantly decreased relative to preoperative scores and appear to have been sustained at follow-up times to 1 year. It is unclear whether one treatment provided superior pain relief than the other. Both studies reported decreased analgesic use after both treatments but neither study compared use between treatment groups. Balloon rupture occurred in one kyphoplasty patient in one study and extravasation of polymethylmethacrylate (PMMA) cement into the anterior perivertebral soft tissue was seen in another patient in the vertebroplasty group and no patients in the kyphoplasty group in the other study. No other intraoperative or postoperative complications occurred.

Conclusions: There is only limited evidence from comparative studies (two small retrospective cohort studies) regarding the benefits of vertebroplasty versus kyphoplasty in patients with spinal fractures caused by tumors. Both appear to be effective in reducing pain with relatively few complications. Whether one method provides superior results over the other cannot be determined from the available evidence. Study limitations preclude making definitive conclusions. The overall strength of evidenced is very low.

This systematic review was funded by AOSpine. 


\section{STUDY RATIONALE AND CONTEXT}

Oncological treatment has undergone major evolution in the recent decades leading to decreased patient mortality. However, the rate of bony metastases has increased over the years [1]. The spine is among the most common location for bony metastases. In many cases these metastases cause fractures due to voids created by the treatment or by the tumor itself, leading to increased morbidity. Over the past decade percutaneous cement augmentation techniques have been developed for the treatment of these fractures. The two most common techniques are vertebroplasty and kyphoplasty. Vertebroplasty is a technique in which cement is injected into the vertebrae; kyphoplasty uses a balloon to create a void in the vertebrae into which the cement is injected. There are little data comparing these interventions.

\section{CLINICAL QUESTION}

Do comparative studies of vertebral cement augmentation for fractures due to spinal tumors provide evidence of improved patient outcomes?

\section{METHODS}

Study design: Comparative effectiveness review.

Search: PubMed, EMBASE, Cochrane Database of Systematic Reviews, bibliographies of key articles.

Dates searched: up through June 8, 2011.

Inclusion criteria: Studies directly comparing cement augmentation via vertebroplasty or kyphoplasty with other treatment methods or with each other (CoE I-III) in patients with metastatic or primary tumors in the spine.

Exclusion criteria: Spinal fractures due to trauma or osteoporosis; patients undergoing trauma surgery, decompression, or spinal fusion.

Outcomes: Pain, functional outcomes, longevity, hospitalization time, and complications.

Analysis: Descriptive statistics.

Additional methodological and technical details are provided in the Web Appendix at www.aospine.org/ebsj

\section{RESULTS}

- Two small retrospective cohort studies (LoE-III; 83 patients, 147 levels) comparing vertebroplasty with kyphoplasty that met the inclusion criteria were identified and are summarized (Fig1) [2, 3]. Mean patient age was 62.5 years, women comprised $48.2 \%$ of the population, and the most common cancer diagnosis was primary multiple myeloma (Table 1). Additional details can be found in the Web Appendix at www. aospine.org/ebsj.

- A systematic review of vertebroplasty, kyphoplasty, and embolization for the treatment of spinal tumors was also identified [4]. Although the two studies identified by our search were included, this review primarily summarized case series and did not meet the inclusion criteria. Two additional systematic reviews $[5,6]$ that included many of the same case series were found and likewise did not meet inclusion criteria.

Fig 1 Results of literature search.

1. Total citations $(\mathrm{N}=36)$

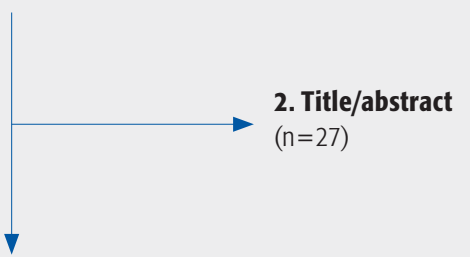

3. Retrieved for full-text evaluation $(n=9)$

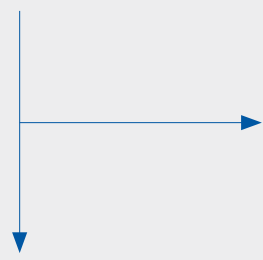

4. Excluded at full-text review $(n=7)$

5. Included publications

$(n=2)$ 
Table 1 Summary of population characteristics and intervention details for included studies comparing VP with KP for treatment of spinal fractures caused by tumors.*

\begin{tabular}{|c|c|c|c|c|c|c|}
\hline Study & $\begin{array}{l}\text { Study } \\
\text { design } \\
\text { (LoE) }\end{array}$ & $\begin{array}{l}\text { Follow-up } \\
\text { (\% followed up) }\end{array}$ & Demographics & Patient characteristics & Interventions & Inclusion/exclusion \\
\hline 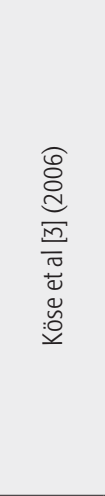 & $\begin{array}{l}\text { Retrospective } \\
\text { cohort } \\
\text { (LoE-III) }\end{array}$ & 1 y (NR) & $\begin{array}{l}\text { KP } \\
\text { - } n=18 \\
\text { - Female: } 50 \% \\
\text { - Age: } \\
64 \text { y }(48-82 \text { y) } \\
\text { PVP } \\
\text { - } n=16 \\
\text { - Female: } 56 \% \\
\text { - Age: } \\
62 \text { y }(45-80 y)\end{array}$ & $\begin{array}{l}\text { - Fracture type: pathological, } \\
\text { symptomatic } \\
\text { - All patients diagnosed with } \\
\text { primary multiple myeloma } \\
\text { - Total vertebral treated: } 50 \text { (22 } \\
\text { KP; } 28 \text { VP) } \\
\text { - Fracture distribution: } \\
\text { - KP: } 15 \text { lumbar, } 7 \text { thoracic } \\
\text { - VP: } 13 \text { lumbar, } 15 \text { thoracic } \\
\text { - Fracture age: NR } \\
\text { - Crossover: NR }\end{array}$ & $\begin{array}{l}\text { - KP and VP using PMMA } \\
\text { bone cement mixed with } \\
\text { barium } \\
\text { - Both procedure used } \\
\text { continuous image } \\
\text { intensifier and local } \\
\text { anesthesia with patient } \\
\text { under moderate sedation } \\
\text { - Allocation criteria: } \\
\text { - KP: }>50 \% \text { compression } \\
\text { - VP: }<50 \% \text { compression }\end{array}$ & $\begin{array}{l}\text { Included } \\
\text { - Primary multiple myeloma } \\
\text { - Symptomatic compression } \\
\text { fractures } \\
\text { - Unresponsive to } \\
\text { conservative treatment } \\
\text { - Treated between June } 2003 \\
\text { and June } 2005 \\
\text { Excluded } \\
\text { - History of acute traumatic } \\
\text { event } \\
\text { - Vertebral biopsy did not } \\
\text { confirm myeloma metastasis }\end{array}$ \\
\hline 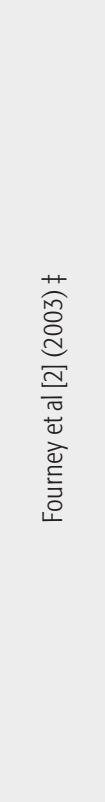 & $\begin{array}{l}\text { Retrospective } \\
\text { cohort } \\
\text { (CoE-III) }\end{array}$ & $\begin{array}{l}\text { Median follow-up: } \\
4.5 \mathrm{mo} \\
\text { Patients available at } \\
\text { each interval: } \\
-1 \mathrm{mo}, \mathrm{n}=41(73 \%) \\
-3 \mathrm{mo}, \mathrm{n}=37(66 \%) \\
-6 \mathrm{mo}, \mathrm{n}=121 \\
(38 \%) ; \\
-1 \mathrm{y}, \mathrm{n}=8(14 \%)\end{array}$ & $\begin{array}{l}\text { KP } \\
\text { - } n=15 \\
\text { - Female: } 47 \% \\
\text { - Age: NR } \\
\text { PVP } \\
\text { - } n=34 \\
\text { - Female: 44\% } \\
\text { - Age: NR } \\
\text { Both PVP and KP§ } \\
\text { - } n=7 \\
\text { - Female: 43\% } \\
\text { - Age: NR }\end{array}$ & $\begin{array}{l}\text { - Fracture type: pathological; } \\
\text { symptomatic } \\
\text { - Most common cancer } \\
\text { diagnosis: multiple myeloma } \\
\text { (KP 40\%; PVP 32\%; KP and } \\
\text { PVP 57\%) } \\
\text { - Mean spinal levels treated per } \\
\text { session: 1.7(1-5) } \\
\text { - Most common level: } \\
\text { thoracolumbar junction } \\
\text { - Median duration of spinal } \\
\text { pain: } 3.2 \text { mo (1 wk to } 26 \text { mo) } \\
\text { - Previous treatment: } \\
\text { - Chemotherapy: 87\% KP; 79\% } \\
\text { PVP; 100\% KP and PVP } \\
\text { - Spinal radiotherapy: 33\% KP; } \\
\text { 29\% PVP; 43\% KP and PVP } \\
\text { - Spinal operation: 27\% KP; 6\% } \\
\text { PVP, } 0 \text { KP and PVP } \\
\text { - PVP or KP: 0 KP; 0 PVP; 14\% } \\
\text { KP and PVP } \\
\text { - Fracture age: NR } \\
\text { - Crossover: NR }\end{array}$ & $\begin{array}{l}\text { - KP and PVP using PMMA } \\
\text { bone cement } \\
\text { - KP through a bilateral } \\
\text { approach } \\
\text { - PVP through a unilateral } \\
\text { approach was used in } \\
\text { most cases } \\
\text { - A transpedicular } \\
\text { approach was preferred } \\
\text { in both procedures } \\
\text { - General or local } \\
\text { anesthesia was in all } \\
\text { cases }\end{array}$ & $\begin{array}{l}\text { Included } \\
\text { - Diagnosis of cancer } \\
\text { - Disabling pain secondary to } \\
\text { pathological thoracic or } \\
\text { lumbar vertebral fractures } \\
\text { - Failed conservative therapy } \\
\text { (analgesic medication, bed } \\
\text { rest, external brace therapy) } \\
\text { - Treated between October } \\
2000 \text { and February } 2002 \\
\text { Excluded } \\
\text { - No cancer diagnosis (ie, } \\
\text { osteoporotic compression } \\
\text { fractures, hemangioma) }\end{array}$ \\
\hline
\end{tabular}

* KP indicates kyphoplasty; VP, vertebroplasty; PMMA, polymethylmethacrylate; PVP, percutaneous vertebroplasty; and NR, not reported.

+ Loss of $>50 \%$ or $<50 \%$ of vertebral height on plain lateral $x$-ray.

‡ Several patients had risk factors for osteoporosis; it was often difficult to determine the extent to which this was responsible for vertebral body collapse compared with a purely osteolytic malignant process.

$\S$ This group was excluded from analysis since only those patients who had one or the other procedure were included.

Table 2 Pain scores from baseline to 1 year in studies comparing VP with KP for the treatment of spinal fractures caused by tumors.*

\begin{tabular}{|c|c|c|c|c|c|c|c|c|c|}
\hline \multirow[t]{2}{*}{ Study } & \multicolumn{2}{|c|}{ Preop } & \multicolumn{2}{|c|}{ 4-6 wk postop } & \multicolumn{2}{|c|}{6 mo postop } & \multicolumn{2}{|c|}{1 y postop } & \multirow{2}{*}{$\boldsymbol{P}_{\text {value }}{ }^{\dagger}$} \\
\hline & VP & KP & VP & KP & VP & KP & VP & KP & \\
\hline Köse et al [3] $(2006)^{\ddagger}$ & $37.8 \pm 3.3$ & $36.0 \pm 4.5$ & $15.3 \pm 4.1$ & $12.1 \pm 3.6$ & $12.2 \pm 3.0$ & $8.6 \pm 2.3$ & $13.5 \pm 2.9$ & $9.7 \pm 2.4$ & $<.001$ \\
\hline Fourney et al [2] (2003)§ & 8 & 8 & 2 & 2.5 & 2 & 4 & 1 & 2 & $<.05$ \\
\hline
\end{tabular}

* Preop indicates preoperative; postop, postoperative; VP, vertebroplasty; and KP, kyphoplasty.

$\dagger$ For preoperative scores compared with all postoperative time points.

₹ Mean scores for pain-related disability. Patients were asked to evaluate five activities of daily living, ie, pain at rest, walking, sitting-standing, taking a shower, and wearing clothes, on a visual analogue scale (VAS) for pain (0-10). The sum of these five score created an overall VAS pain score that was evaluated on a scale of $0-50$, with higher scores indicating greater disability because of pain.

§ Median scores on a VAS pain scale 0-10; estimated from figure 10 in the study. Follow-up at each interval: 41 (73\%) at 1 month; 37 (66\%) at 3 months; $21(38 \%)$ at 6 months; and 8(14\%) at 1 year should be considered when interpreting these results. 


\section{Pain}

Pain scores for both the vertebroplasty and the kyphoplasty groups decreased significantly from preoperative values at follow-up intervals through 1 year (Table 2) [2, 3]. It is not clear which augmentation procedure may yield better pain relief given limitations of these studies.

- One study suggests that kyphoplasty provided better results regarding pain-related disability (composite visual analogue scale (VAS) score, see Table 2) with a significantly greater percentage decrease in pain scores by 6 months and 1 year compared with vertebroplasty: $76.1 \%$ versus $68.1 \%(P=.02)$ and $73 \%$ versus $64.4 \%$ $(P=.03)$, respectively (Fig 2) [3].

- In the second study, based on an average of multiple VAS pain (0-10) measurements within the first 24 hours following vertebroplasty (35 sessions) and kyphoplasty (15 sessions), improvement was also seen in both groups [2]. Similar percentages treatment session for both resulted in improved or complete pain relief; vertebroplasty, $85.8 \%(\mathrm{n}=30$ sessions $)$ and kyphoplasty $80 \%(n=12)$ (Fig 3). Pain relief appears to have been sustained at 1-, 3-, 6-, and 12-month follow-up; however, follow-up rates dropped at each interval: $73 \%$ at 1 month; $66 \%$ at 3 months; $38 \%$ at 6 months; and $14 \%$ at 1 year. This needs to be considered when interpreting the results.

Fig 2 Mean percentage decrease in overall VAS pain scores ${ }^{*}$ from preoperative to specified follow-up after vertebroplasty and kyphoplasty as reported by Köse et al [3] $(\mathrm{N}=34)$.

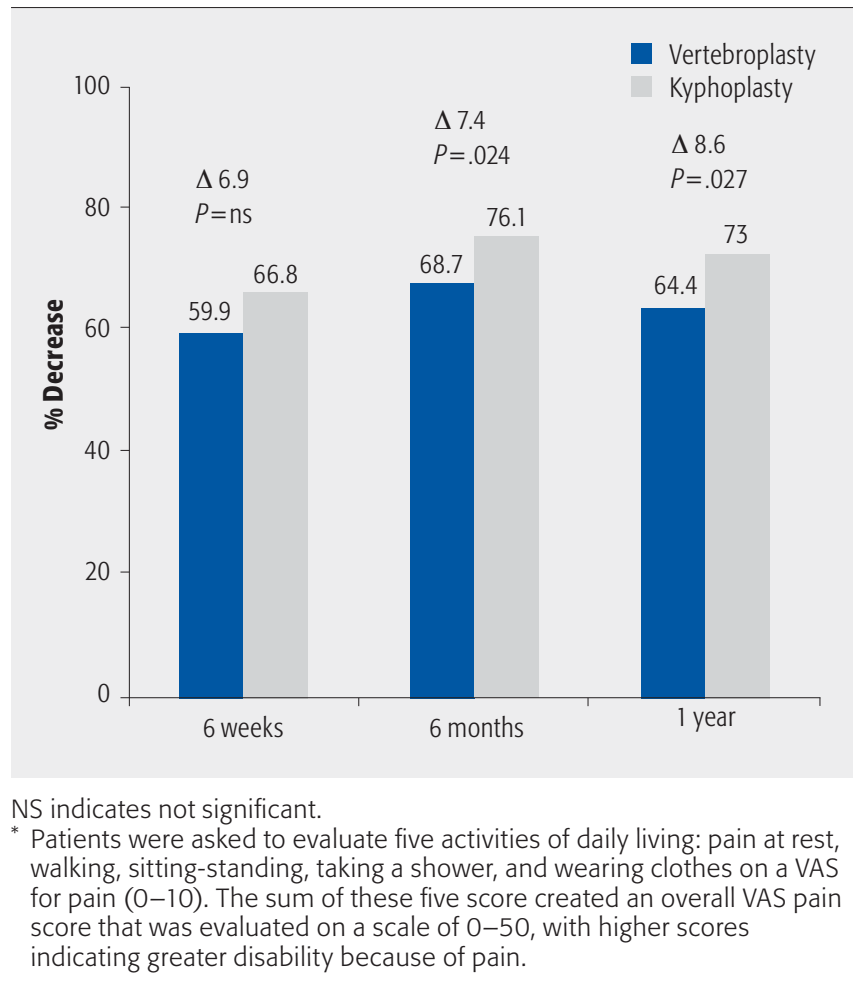

\section{Analgesic use}

- One study reported that all patients receiving augmentation reduced weekly analgesic use at all postoperative times [3]. The other reported a significant change in the category of analgesics used at 1 month but this was not sustained at later follow-up [2].

- Neither study reported on differences in analgesic use between treatment groups.

\section{Complications}

- Balloon rupture occurred in one kyphoplasty patient in one study [3]. No other adverse outcomes, such as adjacent level fractures, intraoperative or postoperative neurological or pulmonary complications, were reported in either group.

- In the second study, extrusion of polymethylmethacrylate (PMMA) was noted on image intensifier during injection in six patients $(17.6 \%)$ in the vertebroplasty group and no patients in the kyphoplasty group [2]. Extravasation of PMMA into the anterior perivertebral soft tissue was seen in one patient in the vertebroplasty group and no patients in the kyphoplasty group. No cement extravasation into the epidural space or neural foramen was reported in any patient in either group. No procedure-related deaths or intraoperative or perioperative complications were reported.

Fig 3 Percentage of sessions resulting in pain relief during the first 24 hours, ${ }^{*}$ vertebroplasty or kyphoplasty reported by Fourney et al [2] $(\mathrm{N}=49)$.

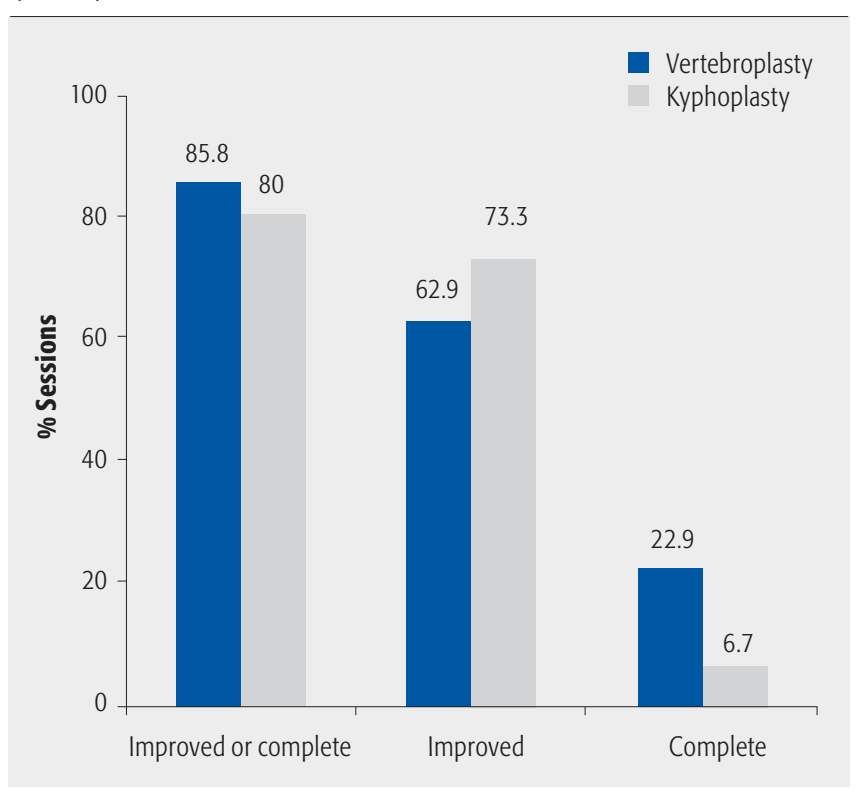

* Based on VAS pain scores within the first 24 hours. Multiple measurements during that period were averaged. Data available: vertebroplasty, $n=33$ sessions; kyphoplasty, $n=13$ sessions. Complete pain relief was reported for 8 (22.9\%) vertebroplasty sessions and 1 (6.7\%) kyphoplasty session. 


\section{CLINICAL GUIDELINES}

National Institute for Health and Clinical Excellence (NICE) One clinical guideline by NICE was found via the National Guideline Clearinghouse that addressed the topic of vertebroplasty and kyphoplasty for the treatment of spinal fractures caused by vertebral metastases and provided the following summary statement:

"Both of these minimally invasive techniques [vertebroplasty and kyphoplasty] have NICE Interventional Procedures Guidance which permits their use in persistently painful spinal fracture including metastatic disease. The evidence of effectiveness in treating metastatic involvement is small in comparison with that for osteoporotic collapse, but there is considerable interest in their potential to reduce pain and avert vertebral collapse/metastatic spinal cord compression (MSCC). There are risks involved, including cement leakage causing spinal cord compression which may require urgent or emergency surgical intervention [7]."

\section{Recommendations:}

- Consider vertebroplasty or kyphoplasty for patients who have vertebral metastases and no evidence of metastatic spinal cord compression or spinal instability if they have:

- mechanical pain resistant to conventional analgesia, or

- vertebral body collapse.

- Vertebroplasty or kyphoplasty for spinal metastases should only be performed after agreement between appropriate specialists (including an oncologist, interventional radiologist, and spine surgeon) with full involvement of the patient and in facilities with good access to spine surgery.

\section{ILLUSTRATIVE CASE}

A 66-year-old man with known metastatic renal cell carcinoma (clear cell) presented with back pain. An x-ray revealed pathological fractures in the $\mathrm{T} 9$ and $\mathrm{T} 7$ vertebrae (Fig 4). The patient was treated with oral narcotics but the pain did not resolve, so kyphoplasty of $\mathrm{T} 9$ and $\mathrm{T} 7$ with cement augmentation of T8 was performed under general anesthesia (Figs 5 and 6). A postoperative computed tomography showed good filling of the vertebrae without penetration (Fig 7). Following the procedure, the patient's pain subsided and he regained full mobility allowing improved quality of life.
Fig 4 Sagittal view of the spine demonstrating pathological fractures at the T9 and T7 vertebrae.

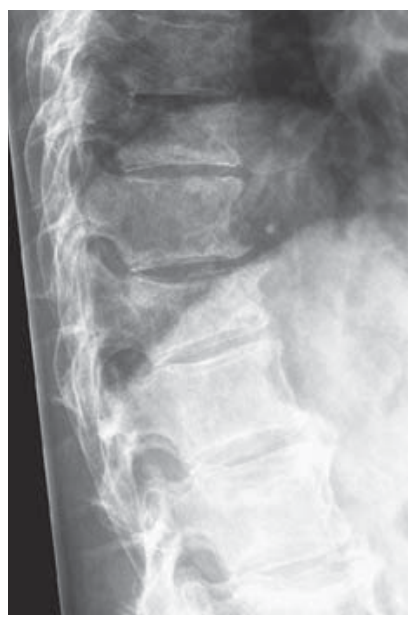

Fig 5 Sagittal view of the spine following kyphoplasty of T9 and T7 with cement augmentation of T8.

Fig 6 AP view of the spine following kyphoplasty of T9 and T7 with cement augmentation of T8.
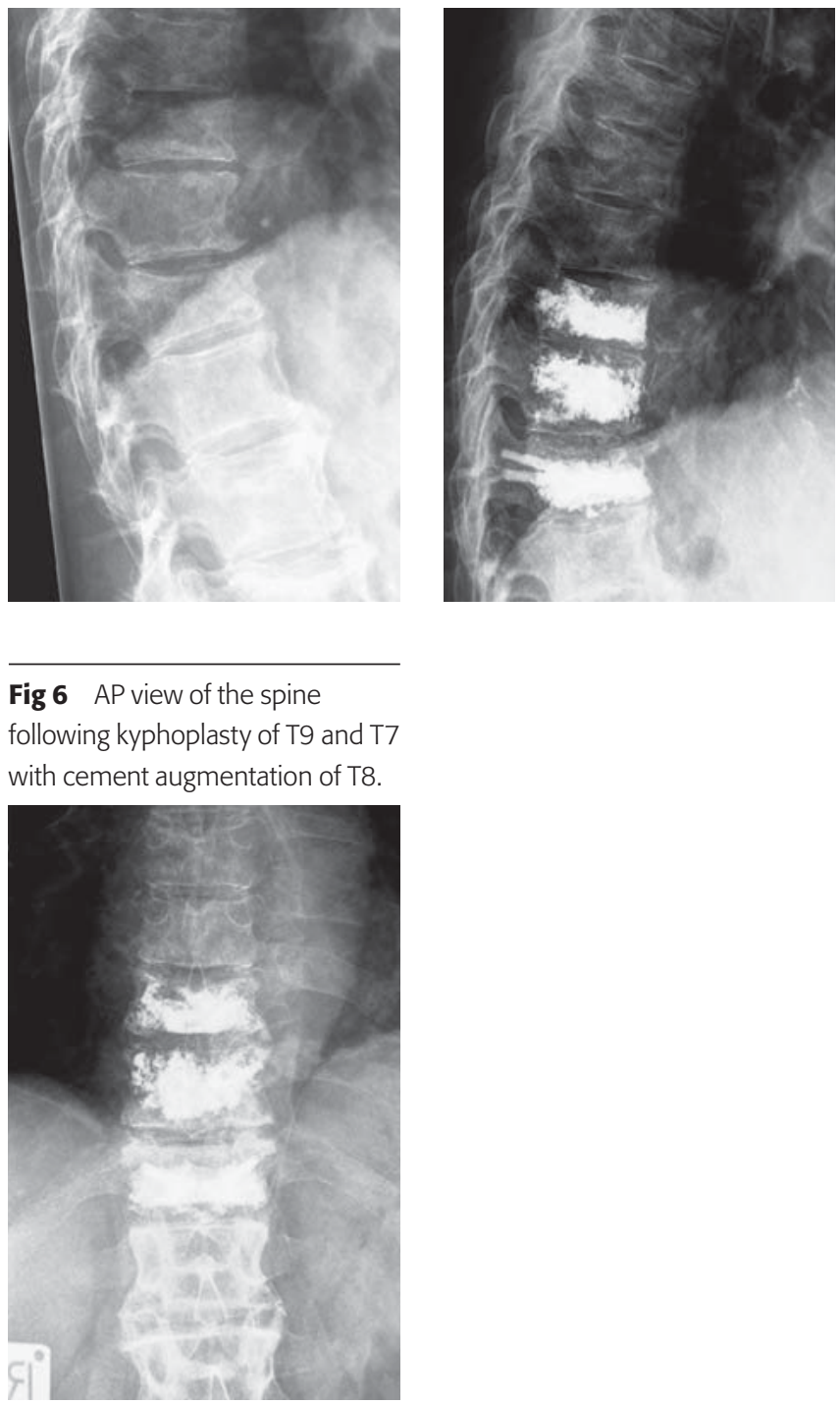


\section{DISCUSSION}

- There is limited information from comparative studies on the benefits and harms of cement augmentation methods for the treatment of tumor-related fractures.

- Both procedures adequately provide pain management, the main indication for the procedure.

- In many studies, vertebral body height is better restored with kyphoplasty. The included study by Fourney et al [2] reported a mean percentage of restored height of $42 \% \pm 21 \%$. In this analysis the benefit of kyphoplasty could not be determined and the link between height and functional outcomes was not evaluated.

- Conclusions from this review of the two comparative studies identified are limited by the following:

- Pain outcomes and analgesic use were defined differently making comparisons across them difficult. Definitions for clinically meaningful changes in pain score were not described in either study. The small sample sizes may preclude the evaluation of rare complications and preclude meaningful statistical analysis.

- Neither study was designed to rigorously compare vertebroplasty and kyphoplasty. Treatment selection based on patient presentation may lead to biased results for comparison.

- Significant loss to follow-up in the one study and inability to determine the number of eligible patients (and therefore loss to follow-up) should be considered when interpreting these results and drawing conclusions about sustained benefits.
The review by Mendel et al [4] primarily included case series. Data specific to patients with tumors were summarized as follows (Tables 3-5):

- In 11 prospective studies, $74.5 \%$ of vertebroplasty patients and $44.6 \%$ of kyphoplasty patients had metastases. Multiple myeloma was reported in $23.5 \%$ and $55.4 \%$, respectively.

- Overall, improvement in pain scores and function relative to baseline was seen across all studies for both vertebroplasty and kyphoplasty, but measures varied across studies.

- For vertebroplasty and kyphoplasty, respectively, reported complication rates were: medical, $0 \%$ and $0.5 \%$; neurological, $4.1 \%$ and $0 \%$; corrective surgery, $3.1 \%$ and $0 \%$; symptomatic cement extravasation, $3.1 \%$ and $0 \%$; total extravasation per level, $58.5 \%$ and $12.1 \%$; and adjacent vertebral fracture, $0 \%$ and $2.9 \%$.

- In the absence of studies directly comparing cement augmentation with usual care or other treatment options, evidence-based conclusions regarding the comparative effectiveness of vertebroplasty or kyphoplasty are not possible.

Data from two other systematic reviews suggests the following (Tables 3-5) [5, 6]:

- Cement leakage is much more common following vertebroplasty compared with kyphoplasty with up to $79 \%$ versus $6 \%$ of patients experiencing this, respectively; however, few symptomatic leaks were noted in either group, $0.26 \%$ versus $0 \%$, respectively.

- New fractures occurred in $10.2 \%$ of patients based on pooled estimates across four reports on kyphoplasty [5]. 
Table 3 Overview of systematic reviews that included studies on fractures due to pathological fractures.*

\begin{tabular}{|c|c|c|c|}
\hline $\begin{array}{l}\text { Study } \\
\text { (search datef) }\end{array}$ & No. of studies, patients $\mathrm{F} / \mathrm{U}$ & $\begin{array}{l}\text { Interventions } \\
\text { evaluated }\end{array}$ & Critical appraisal comments \\
\hline $\begin{array}{l}\text { Lee et al [6] (2009; } \\
\text { Dec 2006) }\end{array}$ & $\begin{array}{l}N=20 \text { studies } \\
\text { - PV: } n=13 \text { studies; } N \text { patients NR; } \\
760 \text { levels } \\
\text { - KP: } n=7 ; N \text { patients NR; } 214 \text { levels } \\
\text { - F/U =NR }\end{array}$ & $P V$ and $K P$ & $\begin{array}{l}\text { - Specifically selected studies (case series and comparative) addressing complications } \\
\text { - No formal critical appraisal of included studies or evaluation of heterogeneity } \\
\text { - Outcomes for tumor-related fractures separated only for cement leakage ( } n=20 \\
\text { studies) } \\
\text { - Pooled estimates weighted by sample size }\end{array}$ \\
\hline $\begin{array}{c}\text { Bouza et al [5] } \\
\text { (2009; Sept 2008) }\end{array}$ & $\begin{array}{l}\text { - } \mathrm{N}=7 \text { studies ( } 3 \text { retrospective; } 4 \\
\text { prospective) } \\
-\mathrm{N}=306 \text { patients, } 741 \text { levels } \\
\text { - F/U 3-24 mo }\end{array}$ & KP only & $\begin{array}{l}\text { - Appears to have included } 5 \text { case series and } 2 \text { comparative studies } \\
\text { - Critical appraisal described } \\
\text { - Metaanalysis using random effects } \\
\text { - Evaluated sources of heterogeneity }\end{array}$ \\
\hline $\begin{array}{c}\text { Mendel et al [4] } \\
\text { (2009; Sept 2008) }\end{array}$ & $\begin{array}{l}\text { - PV: } N=5 \text { prospective studies } 98 \\
\text { patients, } 152 \text { levels (estimated) } \ddagger \\
\text { - KP: } N=6 \text { prospective studies } 204 \\
\text { patients, } 330 \text { levels (estimated) } \ddagger\end{array}$ & $P V$ and $K P$ & $\begin{array}{l}\text { - Primarily case series; information on prospective studies available } \\
\text { - Prospective studies classified as level II; retrospective as level III by authors; no } \\
\text { formal critical appraisal described } \\
\text { - Focus: studies of malignant fractures and included studies of tumor embolization } \\
\text { - Reports summary data for prospective studies but cites heterogeneity concerns and } \\
\text { no metaanalysis performed }\end{array}$ \\
\hline
\end{tabular}

* F/U indicates follow-up; KP, balloon kyphoplasty; PV, percutaneous vertebroplasty; and NR, not reported. Pathological fractures may include multiple myeloma, hemangioma, or metastases.

$\dagger$ First date is year of publication, second is last date reported for literature search.

‡ Some included studies did not report number of levels per tumor patient.

Table 4 Summary of pooled estimates of cement leakage from systematic reviews of studies on pathological fractures.*

\begin{tabular}{|c|c|c|c|c|c|}
\hline \multirow{2}{*}{ Study } & \multirow{2}{*}{ No. of studies } & \multicolumn{2}{|l|}{ Any leak ${ }^{\dagger}$} & \multicolumn{2}{|l|}{ Symptomatic ${ }^{\ddagger}$} \\
\hline & & PV & KP & PV & KP \\
\hline Lee et al [6] (2009) & $\begin{array}{l}\text { - } \mathrm{PV}: \mathrm{N}=13 \text { (1 prospective) } \\
-\mathrm{KP}: \mathrm{N}=7 \text { (2 prospective) }\end{array}$ & $\begin{array}{l}\text { All studies (per level) } \\
-79.07 \% \text { (601/760 levels) }\end{array}$ & $\begin{array}{l}\text { All studies (per level) } \\
-6.07 \% \text { (13/214 levels) }\end{array}$ & $\begin{array}{l}\text { All studies (per level) } \\
-0.26 \% \text { (21/760 levels) }\end{array}$ & $\begin{array}{l}\text { All studies (per level) } \\
-0.0 \%(0 / 214 \text { levels) }\end{array}$ \\
\hline Bouza et al [5] (2009) & $\begin{array}{l}\text { - KP only: } \\
\text { N=7 studies } \\
\text { (4 prospective) }\end{array}$ & NA & $\begin{array}{l}\text { All studies } \\
-5.8 \%(1.96,9.64 \%) \\
(41 \text { leaks, presume levels } \\
\text { reported })^{\S} \\
\text { Prospective studies } \\
-11.2 \% \S \\
\text { Retrospective studies } \\
-0.51 \%{ }^{\S}\end{array}$ & NA & $-0.0 \%$ \\
\hline Mendel et al [4] (2009) & $\begin{array}{l}\text { - PV: } N=5 \text { studies } \\
-K P: N=6 \text { studies }\end{array}$ & $\begin{array}{l}\text { Prospective studies } \\
-58.4 \% \text { (59/101 levels) }\end{array}$ & $\begin{array}{l}\text { Prospective studies } \\
-12.1 \% \text { (12/2391 levels) }\end{array}$ & $\begin{array}{l}\text { Prospective studies } \\
-3.1 \% \text { (3/98 patients) }\end{array}$ & $\begin{array}{l}\text { Prospective studies } \\
-0 \%\end{array}$ \\
\hline
\end{tabular}

* KP indicates balloon kyphoplasty; NA, not applicable; and PV, percutaneous vertebroplasty.

$\dagger$ Authors may report rate per number of patients or number of levels treated (level) or number of vertebrae as noted in the table.

₹ Pathological fractures may include multiple myeloma, hemangioma, or metastases.

$\S$ Effect size and 95\% confidence interval based on random effects model.

Table 5 Other complications from systematic reviews.*

\begin{tabular}{llll}
\hline & Complication & PV & KP \\
\hline Mendel et al [4] (2009) & - Neurological (not specified) & $-4.1 \%$ (4/98 patients) & $-0 \%$ \\
& $-N=11$ prospective studies & & \\
\hline Bouza et al [4] (2009) & - Any new fracture & - NA & $-10.23 \%$ \\
& - KP only: $N=4$ studies & & $(2.8,17.66 \%)(21 / 172$ patients) \\
\hline
\end{tabular}

* PV indicates percutaneous vertebroplasty; KP, balloon kyphoplasty; and NA, not applicable. Effect size and 95\% confidence interval based on random effects model. 


\section{CONCLUSION}

Vertebroplasty or kyphoplasty should be considered for patients with pain who have vertebral metastases and no evidence of metastatic spinal cord compression or spinal instability. The main advantage of kyphoplasty is a better controlled cement placement. Limited data are available from existing comparative studies and case series, making firm conclusions regarding benefit difficult. A welldesigned comparative study is warranted in order to see if any clinical difference between augmentation techniques and/or other treatment options exists.

\section{EVIDENCE SUMMARY}

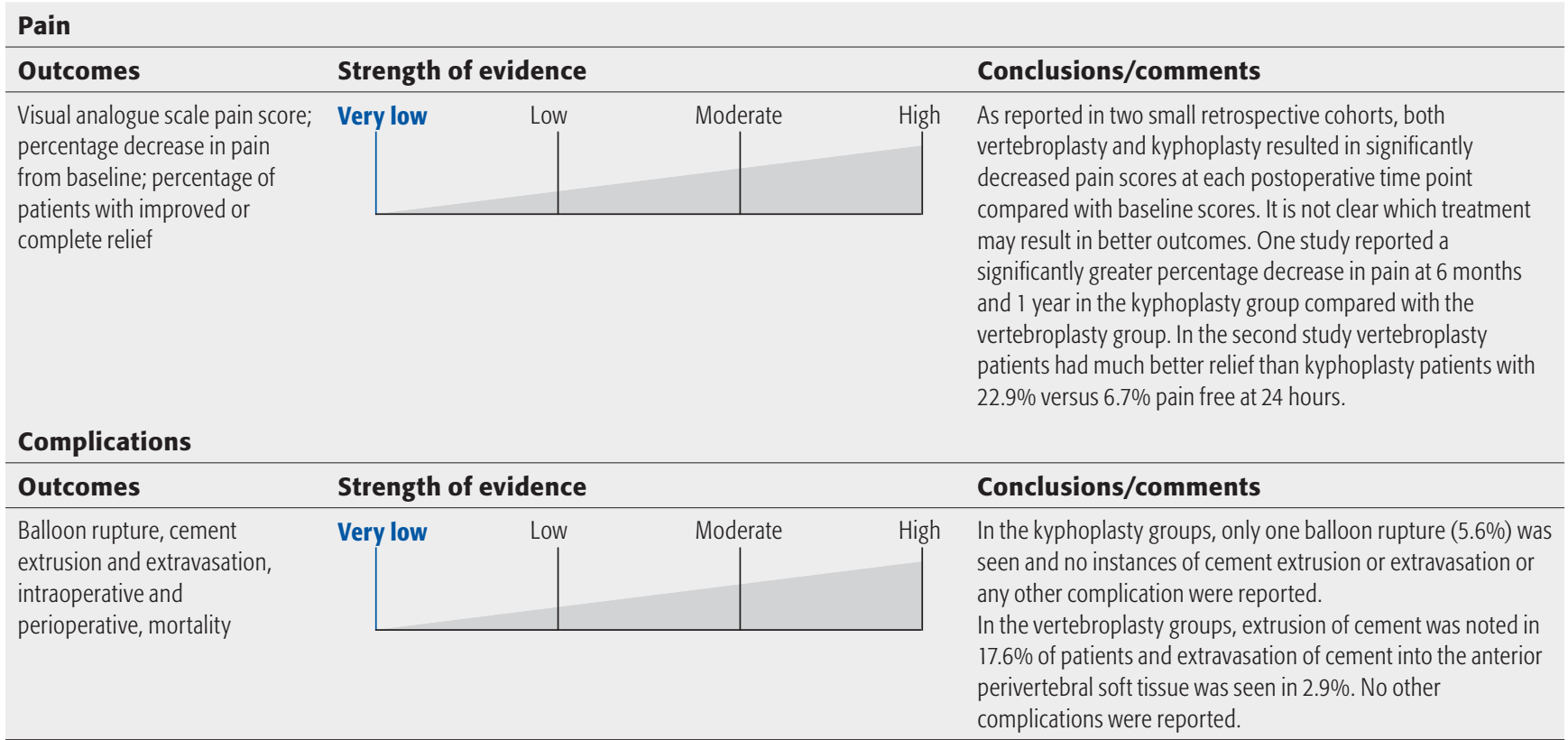




\section{REFERENCES}

1. Chow E, Harris K, Fan G, et al (2007) Palliative radiotherapy trials for bone metastases: a systematic review. J Clin Oncol; 25(11):14231436.

2. Fourney DR, Schomer DF, Nader R, et al (2003) Percutaneous vertebroplasty and kyphoplasty for painful vertebral body fractures in cancer patients. $J$ Neurosurg; 98 (Suppl 1):21-30.

3. Köse KC, Cebesoy O, Akan B, et al (2006) Functional results of vertebral augmentation techniques in pathological vertebral fractures of myelomatous patients. J Natl Med Assoc; 98(10):1654-1658.

4. Mendel E, Bourekas E, Gerszten P, et al (2009) Percutaneous techniques in the treatment of spine tumors: what are the diagnostic and therapeutic indications and outcomes? Spine; 34(Suppl 22):S93-100.

5. Bouza C, Lopez-Cuadrado $T$, Cediel $\mathbf{P}$, et al (2009) Balloon kyphoplasty in malignant spinal fractures: a systematic review and meta-analysis. BMC Palliat Care; 8:12.

6. Lee MJ, Dumonski M, Cahill $P$, et al (2009) Percutaneous treatment of vertebral compression fractures: a meta-analysis of complications. Spine (Phila Pa 1976); 34(11):1228-1232.

7. National Collaborating Centre for Cancer (2008) Metastatic spinal cord compression: diagnosis and management of adults at risk of and with metastatic spinal cord compression. National Institute for Health and Clinical Excellence (NICE). Available at: www.guideline.gov

\section{EDITORIAL PERSPECTIVE}

Schroeder and colleagues are praised for their topic selection and their diligent analysis. There are concerns about the surprisingly low number of studies, which pertained to a comparison of vertebroplasty and kyphoplasty in the setting of metastatic spine disease. Rather than not publishing this article we believed that the existing studies contained valuable information and that our readership will be inspired to fill the apparent void in the published literature with their own efforts.

Of course, any future well-designed and sufficiently powered study holds a high likelihood of changing our treatment recommendations regarding vertebroplasty/kyphoplasty in metastatic disease to the spinal column substantially.

Our reviewers commented on a number of issues which were not addressed in the current studies:

- Neurological compromise: patients with present or pending neurological compromise from metastatic disease are not suitable candidates for vertebral augmentation with bone cement. Conventional decompression and reconstruction with or without cement is favored in this setting.

- Angulation: correction of kyphosis with any form of cementing technique is limited; if kyphosis is a concern, again conventional surgery is likely preferable.

- Osteolysis: in osteoblastic lesions introduction of polymethylmethacrylate (PMMA) is likely associated with much higher-filling pressures compared with a lytic lesion and thus may be undesirable.

- PMMA extrusion rates: the quoted numbers of extrusion in this article are somewhat lower than those reported for studies dedicated to this subject and may reflect incomplete postoperative imaging or follow-up [1].

- Disease spread and tissue type: the roles of radiation therapy (with multiple different variations becoming increasingly available), surgery (conventional open versus minimally invasive), local augmentation procedures, and staging with chemotherapy are some of the management variables and have to be correlated with general patient health, neurological status, tumor type and expected response rates, and a host of other factors. Such a host of variables makes it desirable to link key centers into larger investigative units to gain better insights into results and advancements.

The newly formed AOSpine Knowledge Forum Neoplasia offers an opportunity to participate in an international effort to improve on our state of tumor care in the spine, please go to: $w w w . a o s p i n e . o r g / r e s e a r c h . a s p x$ for more information.

1. Patel AA, Vaccaro AR, Martyak GG, et al (2007) Neurologic deficit following percutaneous vertebral stabilization. Spine (Phila Pa 1976); 32(16):1728-1734. 